\title{
Revegetating spotted knapweed infested rangeland in a sin- gle entry
}

\author{
ROGER L. SHELEY, JAMES S. JACOBS, AND DANIEL E. LUCAS
}

Authors are associate professor, post-doctoral research associate, and Granite County Extension Agent, Department of Land Resources and Environmental Sciences, Montana State University, Bozeman, Mont. 59717.

Abstract

Introducing and establishing competitive plants is essential for the successful management of spotted knapweed (Centaurea maculosa Lam.) infested rangeland where a desirable understory is absent. Our objective was to determine a herbicide-mix that would maximize grass establishment in spotted knapweed-cheatgrass (Bromus tectorum L.) bluegrass (Poa pratensis L.) infested rangeland in a single fall application. On 2 sites in Montana, 8 herbicide treatments [none, glyphosate ( $\mathrm{N}$-[phosphonomethyl] glycine) at $0.5 \mathrm{~kg}$ a.i. $\mathrm{ha}^{-1}$, picloram (4-amino-3,5,6-trichloropicolinic acid, potassium salt) at $0.14 \mathrm{~kg}$ a.i. $\mathrm{ha}^{-1}$, picloram at $0.28 \mathrm{~kg}$ a.i.ha ${ }^{-1}$, clopyralid (3,6-dichloro-2-pyrdinecarboxylic acid, monoethanolamine salt) at $0.21 \mathrm{~kg}$ a.i. $\mathrm{ha}^{-1}$ plus $2,4-\mathrm{D}(2,4-$ dichlorophenoxyacetic acid) at $1.12 \mathrm{~kg}$ a.i. $\mathrm{ha}^{-1}$, picloram at 0.14 $\mathrm{kg}$ a.i. $\mathrm{ha}^{-1}$ plus glyphosate at $0.5 \mathrm{~kg}$ a.i. ha ${ }^{-1}$, picloram $0.28 \mathrm{~kg}$ a.i.ha ${ }^{-1}$ plus glyphosate at $0.5 \mathrm{~kg}$ a.i. $\mathrm{ha}^{-1}$, and clopyralid $0.2 \mathrm{~kg}$ a.i. ha ${ }^{-1}$ plus $2,4-D$ at $1.12 \mathrm{~kg}$ a.i. ha $^{-1}$ plus glyphosate $0.5 \mathrm{~kg}$ a.i. $\mathrm{ha}^{-1}$ ] and 3 seeded grass species ['Luna' pubescent wheatgrass [Thinopyrum intermedium (Host) Barkworth \& D.R. Dewey], bluebunch wheatgrass [Pseudorogneria spicata (Pursh.) Löve], and 'Bozoyski' Russian wildrye [Psathyrostachys junceae (Fisch.) Nevski] were applied in a split-plot design with 4 replications in the late-fall of 1994 and 1995. Spotted knapweed and grass density were measured in 1995, 1996, and 1997, and biomass was measured in 1997 at peak standing crop. Density data were analyzed as a split-split-plot in time, and biomass data were analyzed as a split-plot using analysis of variance. By the end of the study, picloram applied at either 0.14 or $0.28 \mathrm{~kg}$ a.i. $\mathrm{ha}^{-1}$ in the late-fall consistently yielded lowest spotted knapweed density and biomass. Initially, glyphosate alone lowered spotted knapweed density and increased grass biomass compared to that of the control. However, glyphosate treated plots had more spotted knapweed and less seeded grass established by the end of the study. 'Luna' pubescent wheatgrass consistently yielded the high test density and biomass of the seeded grasses. We believe a single-entry revegetation program applying picloram in late-fall combined with a fall-dormant seeding will maximize seedling establishment in spotted knapweed infested rangeland.

Key Words: rehabilitation, weed management, reseeding, seedling establishment

Spotted knapweed (Centaurea maculosa Lam.) is a serious threat to the diversity and productivity of rangeland in the western United States. This deep taprooted weed is native to grassland

\section{Resumen}

La introducción y establecimiento de plantas competitivas es esencial para un manejo exitoso de pastizales infestados con "Spotted knapweed"(Centaurea maculosa Lam.) carentes de vegetación herbácea deseable. Nuestro objetivo fue determinar una mezcla de herbicidas que con una sola aplicación en otoño maximizara el establecimiento de zacates en un pastizal infestado con "Spotted knapweed-Cheatgrass"(Bromus tectorum L.) y "Bluegrass" (Poa pratensis L.). En dos sitios de Montana, a fines de otoño, se aplicaron 8 tratamientos de herbicidas [control (no herbicida), glifosato ( $\mathrm{N}$-[fosfonometil] glicine) en dosis de $0.5 \mathrm{~kg}$ i.a. ha $^{-1}$, picloram (sal de potasio , 4-amino-3,5,6 ácido tricloropicolinico) en dosis de $0.14 \mathrm{~kg}$ i.a. ha ${ }^{-1}$, picloram en dosis de $0.28 \mathrm{~kg}$ i.a. ha $^{-1}$ clopiralid, (sal monoetanolamina, 3,6 dicloro-2- ácido pirdinecarboxilico) en dosis de $0.21 \mathrm{~kg}$ i.a. $\mathrm{ha}^{-1}$ mas 2,4-D (2,4ácido diclorofenoxiacetico) en dosis de $1.12 \mathrm{~kg}$ i.a. ha $^{-1}$, picloram en dosis de $0.14 \mathrm{~kg}$ i.a. $\mathrm{ha}^{-1}$ mas glifosato en dosis de $0.5 \mathrm{~kg}$ i.a. ha- ${ }^{-1}$, picloram en dosis de $0.28 \mathrm{~kg}$ i.a. $\mathrm{ha}^{-1}$ mas glifosato en dosis de 0.5 $\mathrm{kg}$ i.a. $\mathrm{ha}^{-1}$ y clopiralid en dosis de $0.2 \mathrm{~kg}^{\text {i.a. }} \mathrm{ha}^{-1}$ mas 2,4-D en dosis de $1.12 \mathrm{~kg}$ i.a. ha ${ }^{-1}$ mas glifosato en dosis de $0.5 \mathrm{~kg}$ i.a. ha $\left.{ }^{-1}\right] \mathrm{y}$ se sembraron tres especies de zacates "Pubescent wheatgrass" [Thinopyrum intermedium (Host) Barkworth \& D.R. Dewey] variedad 'Luna', "Bluebunch wheatgrass" [Pseudorogneria spicata (Pursh.) Löve], y "Russian wildrye" [Psathyrostachys junceae (Fisch.) Nevski] variedad 'Bozoyski'. Se utilizó un diseño experimental de parcelas divididas con 4 repeticiones. En 1995, 1996 y 1997 se midió la densidad de "Spotted knapweed" y zacates, y en 1997, se midió la biomasa de zacate en la época de mayor producción de forraje en pie. Los datos de densidad se analizaron como parcelas divididas en tiempo y la biomasas se analizó como parcelas divididas utilizando análisis de varianza. Al final del estudio el picloram aplicado en dosis de 0.14 y $0.28 \mathrm{~kg}$ i.a. ha $^{-1}$ tuvieron la mas baja densidad y biomasa de "Spotted knapweed". Inicialmente, comparado con el control, el glifosato solo bajo la densidad de "Spotted knapweed" e incremento la biomasa de zacates.sin embargo, al final del estudio, las parcelas tratadas con glifosato tuvieron mas "Spotted knapweed" y menos plantas establecidas de los zacates sembrados. De los zacates sembrados la especie "Pubecent wheatgrass" variedad 'Luna', produjó la mayor densidad de plantas y biomasa. Creemos que un programa de revegetación de una sola vez mediante la aplicación de picloram a fines del otoño en combinación con la siembra en otoño maximizará el establecimiento de plántulas de zacates en los pastizales infestados de "Spotted knapweed". 
steppes of central Europe and east to central Russia, Caucasia, and western Siberia (Rees et al. 1996). In the United States, spotted knapweed was limited to the San Juan Islands, Wash., until 1920 (Forcella and Harvey 1980). It had spread to 20 counties in the Pacific Northwest by 1960 and to 48 counties by 1980 . Between 1980 and the present, the known range of spotted knapweed rapidly increased to include 326 counties in the western United States, including every county in Idaho, Montana, Washington, and Wyoming (Sheley et al. 1998). Spotted knapweed is detrimental to soil and water resources (Lacey et al. 1989), reduces wildlife and livestock habitat (Watson and Renney 1974, Spoon et al. 1983), and lowers species richness (Tyser and Key 1989).

Over the past several decades, spotted knapweed management has focused on controlling weeds, with limited regard to the composition and persistence of the resulting plant community. It has been proposed that sustainable weed management must focus on establishing desired plant communities that maximize temporal and spatial niche occupation (Sheley et al. 1996). On rangeland devoid of competitive desirable species, weed control is often short-term because desirable species are not available to occupy niches opened by weed control procedures (James 1992, Sheley and Jacobs 1997). In these cases, introducing and establishing competitive plants is essential for the successful management of weed infested rangeland and the restoration of desired plant communities. However, revegetation is often not used as a spotted knapweed management strategy because of the high cost and risk of failure.

Failures in revegetation of weed infested rangeland are usually caused by the combination of a number of factors. The most important are insufficient soil moisture and intense weed competition, and their interaction (Velagala et al. 1997). Inadequate weed control or precipitation usually results in seeding failure, and several attempts at revegetation are required to establish desired stands.

Revegetating spotted knapweed infested rangeland is costly because of the number of attempts required for success and the number of entries onto a site needed to maximize the potential for seedling establishment. Typically, revegetation of weed infested rangeland requires multiple entries. In many situations, the site is disced in late-fall to loosen the soil surface and encourage the germination of weed seeds present in the seedbank. A few weeks later, a nonselective herbicide, such as glyphosate (N-[phosphonomethyl] glycine) is applied to control the newly emerging weeds. The combination of discing and herbicide application reduces the weed seedbank and competition the following spring. Soon after the herbicide is applied, fall dormant grasses are seeded, generally using a no-till drill. The following spring, some of the remaining weed seeds and seeded grasses germinate and emerge. With adequate spring precipitation, both weed and grass seedlings survive. If grass seedlings survive until mid-summer, a reduced rate of 2,4-D (2,4-dichlorophenoxyacetic acid) or mowing is usually applied to reduce the weed competition.

Although revegetation with aggressive species has been shown to limit weed reinvasion (Lym et al. 1997, Whitson et al. 1997), managers are reluctant to attempt it because of this multi-attempt, multi-entry approach. Single-entry revegetation strategies that are cost-effective and reliable must be developed before this important weed management strategy is adopted. Our objective was to determine a herbicide or herbicide-mix that would maximize grass establishment in spotted knapweed-cheatgrass (Bromus tectorum L.)/bluegrass (Poa pratensis L.) infested rangeland in a single fall herbicide and seeding procedure. We hypothesized that picloram (4-amino-3,5,6-trichloropicolinic acid, potassium salt applied at $0.28 \mathrm{~kg}$ a.i. $\left.\mathrm{ha}^{-1}\right)$ plus glyphosate $\left(0.5 \mathrm{~kg}\right.$ a.i. ha $\left.{ }^{-1}\right)$ would provide enough spotted knapweed control to allow establishment of both native and non-native grasses without subsequent re-entry.

\section{Materials and Methods}

\section{Study sites}

Study site 1 (Rock Creek), initiated in 1994 and continued through 1997, was located about $32 \mathrm{~km}$ south of Missoula, Mont. (45 53' 35"N,113 59' 35"W) along Rock Creek, at an elevation of $1,160 \mathrm{~m}$. Study site 2 (Hamilton), initiated in 1995 and continued through 1997 was located about $11 \mathrm{~km}$ east-northeast of Hamilton, Mont. $\left(46^{\circ} 17^{\prime} \mathrm{N}, 114^{\circ} 1^{\prime} \mathrm{W}\right)$ at an elevation of $1,341 \mathrm{~m}$. Both sites are on a Festuca scabrella/Pseudoroegneria spicata habitat type (Mueggler and Stewart 1980). The Rock Creek site was dominated by spotted knapweed with Kentucky bluegrass, smooth bromegrass (Bromus inermis Leyss.), and timothy (Phleum pratense L.) growing in association. The Hamilton site was co-dominated by spotted knapweed and cheatgrass. Rock Creek soils were Bigarm gravely loam (loamyskeletal, mixed, frigid, Typic Eutrochrepts) with zero slope. Hamilton soils were Stecum stony loamy coarse sand (mixed typic Cryorthenths) and were moderately deep. Annual precipitation at both sites ranges from 406 to $457 \mathrm{~mm}$ with a bimodal distribution with peaks in the winter and spring. The mean annual temperature at the Rock Creek is $5.0^{\circ} \mathrm{C}$ and $6.6^{\circ} \mathrm{C}$ at Hamilton.

\section{Procedures}

A fall dormant seeding was applied using 8 herbicide treatments and 3 grass species, with a non-seeded control. Treatments were factorially arranged in a split-plot design with 4 blocks (replications) at each site. The wholeplots were the grass seeding treatments and the subplots were the herbicide treatments.

The herbicide treatments were: none, glyphosate at $0.5 \mathrm{~kg}$ a.i. $\mathrm{ha}^{-1}$, picloram at $0.14 \mathrm{~kg}$ a.i. ha ${ }^{-1}$, picloram at $0.28 \mathrm{~kg}$ a.i. ha $^{-1}$, clopyralid (3,6-dichloro-2-pyrdinecarboxylic acid, monoethanolamine salt) at $0.21 \mathrm{~kg}$ a.i. $\mathrm{ha}^{-1}$ plus $2,4-\mathrm{D}$ at $1.12 \mathrm{~kg}$ a.i. ha ${ }^{-1}$, picloram at $0.14 \mathrm{~kg}$ a.i. ha ${ }^{-1}$ plus glyphosate $0.5 \mathrm{~kg}$ a.i. ha ${ }^{-1}$, picloram 0.28 $\mathrm{kg}$ a.i. $\mathrm{ha}^{-1}$ plus glyphosate at $0.5 \mathrm{~kg}$ a.i. $\mathrm{h}^{-}$ , and clopyralid at 0.21 a.i. ha ${ }^{-1}$ plus 2,4-D at $1.12 \mathrm{~kg}$ a.i. ha ${ }^{-1}$ plus glyphosate $0.5 \mathrm{~kg}$ a.i. ha ${ }^{-1}$. Herbicides were applied within 1 day of seeding using a $\mathrm{CO}_{2}$ pressurized backpack sprayer calibrated to deliver a total volume of 410 liter ha ${ }^{-1}$. Plots at Rock Creek were sprayed on 5 November 1994. The temperature was $3.3^{\circ} \mathrm{C}$, relative humidity was $73 \%$, and winds were calm $\left(<5 \mathrm{~km} \mathrm{hr}^{-1}\right)$. Hamilton plots were sprayed on 7 November 1995. The temperature was $4.2^{\circ} \mathrm{C}$, relative humidity was $65 \%$, and the winds were calm $\left(<5 \mathrm{~km} \mathrm{hr}^{-1}\right)$.

Grass species seeded were 'Luna' pubescent wheatgrass [Thinopyrum intermedium (Host) Barkworth \& D.R. Dewey], bluebunch wheatgrass [Pseudorogneria spicata (Pursh.) Löve], and 'Bozoyski' Russian wildrye [Psathyrostachys junceae (Fisch.) Nevski]. Grasses were seeded using a notill rangeland drill at a rate of $6 \mathrm{~kg} \mathrm{ha}^{-1}$ to a depth of $4 \mathrm{~mm}$. The grass strips were $2.4 \mathrm{~m}$ wide and $63 \mathrm{~m}$ long. The Rock Creek site was seeded 6 November 1994 and the Hamilton site was seeded 8 November 1995.

\section{Sampling}

Density of seeded grasses and spotted knapweed were determined by counting the number of plants in a $0.2 \times 0.5 \mathrm{~m}$ frame randomly placed within each plot in July of 1995 (Rock Creek only) 1996 and 
1997. Biomass of seeded grass, other grass, and spotted knapweed were determined at peak standing crop in August of 1997 by clipping plants to ground level within a circular hoop $0.44 \mathrm{~m}^{2}$ randomly placed within each plot. Plants were separated by species, dried $\left(60^{\circ} \mathrm{C}, 48 \mathrm{hr}\right)$ to a constant weight, and weighed.

\section{Analysis}

Analysis of variance was used to determine the effects of herbicide treatment and grass species seeded on density and biomass of seeded grass, spotted knapweed, and other grass. Sites were analyzed separately. The model used for density analysis was a split-split-plot in time with grass species as the whole-plots, herbicide treatments as the sub-plots, and year as the sub-sub-plots. Seeded grass species effects were tested using block by seeded grass species as the error term. Herbicide treatments and herbicide treatments by seeded grass species effects were tested using block by herbicide treatments by seeded grass species as the error term. Year and all year by herbicide treatments and seeded grass species interactions were tested using the residual as the error term. The model used for biomass analysis was a split-plot with seeded grass species as the whole-plots and herbicide treatments as the sub-plots. Seeded grass species effects were tested using block by seeded grass species as the error term. Herbicide treatments and herbicide treatments by seeded grass species effects were tested using the residual as the error term. When a significant $\mathrm{P}$-value $(\mathrm{P} \leq 0.05)$ was calculated, mean separations for significant main effects and interactions were achieved using Fisher's protected $\mathrm{LSD}_{\propto=0.05}$ comparisons (Peterson 1985).

\section{Results}

\section{Rock Creek}

Spotted knapweed

The effect of herbicide or herbicide combination on spotted knapweed density was dependent upon the year after treatment at Rock Creek (Table 1). All herbicide treatments including either picloram or clopyralid plus 2,4-D yielded similar spotted knapweed density the first (1995) and second (1996) years after application, which ranged from about 3 to 37 plants $\mathrm{m}^{-2}$ (Fig. 1a). In 1997, these treatments maintained spotted knapweed densities below that of the control. Picloram applied at $0.28 \mathrm{~kg}$ a.i. $\mathrm{ha}^{-1}$ or picloram applied at $0.14 \mathrm{~kg}$ a.i. $\mathrm{ha}^{-1}$ plus glyphosate yielded
Table 1. Mean squares generated from analysis of variance of density at Rock Creek, Mont.

\begin{tabular}{lccc}
\hline \hline & & \multicolumn{2}{c}{ Mean Squares } \\
\cline { 3 - 4 } Source & df & Spotted knapweed & Seeded grass \\
\hline Block & 3 & $52,119.9$ & $4,326.0$ \\
Species & 3 & $29,344.7$ & $80,043.8^{*}$ \\
Block * Species & 9 & $49,561.0$ & $7,760.2$ \\
Herbicide & 7 & $988,434.1^{*}$ & $10,899.5^{*}$ \\
Species * Herb & 21 & $21,191.1$ & $5,141.5$ \\
Block*Herb*Species & 84 & $30,040.8$ & $3,734.1$ \\
Year & 2 & $5,287,249.3^{*}$ & $74,258.8^{*}$ \\
Year*Species & 6 & $32,171.1$ & $32,541.4^{*}$ \\
Year*Herb & 14 & $332,621.4^{*}$ & $7,005.3^{*}$ \\
Year*Species*Herb & 42 & $17,585.4$ & $3,838.3$ \\
Residual Error & 192 & $25,381.7$ & $3,932.4$ \\
\hline
\end{tabular}

${ }^{1}$ Asterisk following mean square indicates significant F-test at $\mathrm{P} \leq 0.05$. the lowest density that year, averaging about 108 plants $\mathrm{m}^{-2}$. Spotted knapweed density 3 years after application of picloram applied at $0.14 \mathrm{~kg}$ a.i. $\mathrm{ha}^{-1}$ and picloram applied at $0.28 \mathrm{~kg}$ a.i. $\mathrm{ha}^{-1}$ plus glyphosate was 200 and 212 plants $\mathrm{m}^{-2}$, respectively. Treatments that included clopyralid plus 2,4-D yielded similar spot- ted knapweed density to each other, averaging about 420 plants $\mathrm{m}^{-2}$. Glyphosate increased spotted knapweed density by nearly 55 plants $\mathrm{m}^{-2}$ over that of the control in 1995. The density of spotted knapweed was similar to that of the control 2 (1996) and 3 (1997) years after glyphosate application.
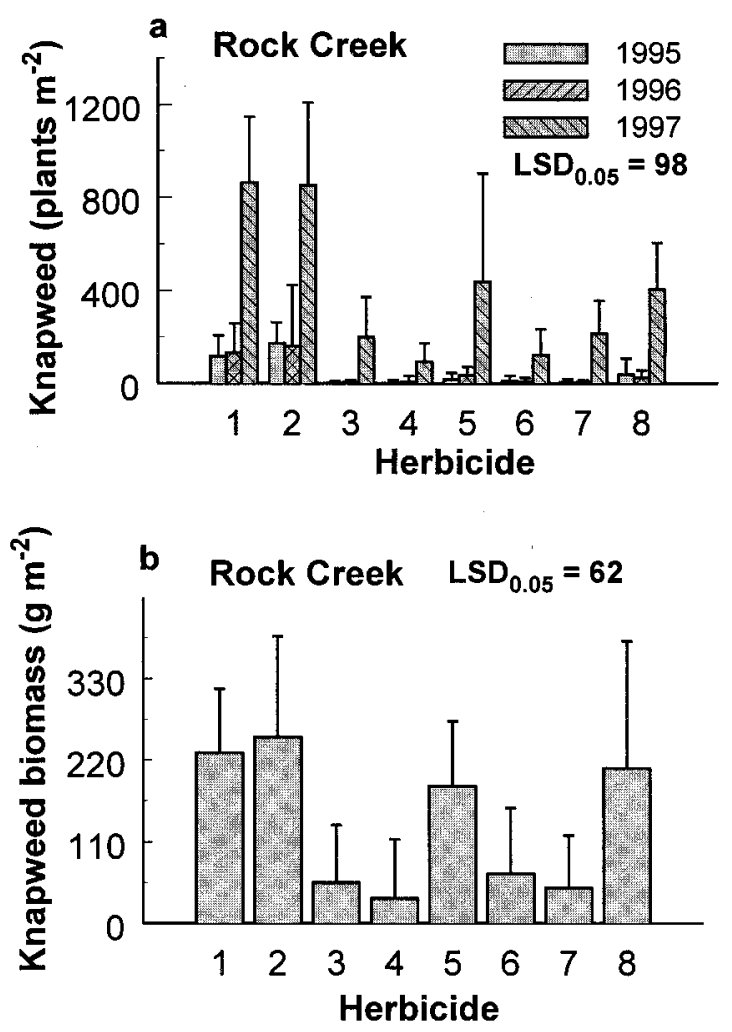

Fig. 1. Effect of herbicide or herbicide combination by year on spotted knapweed density at Rock Creek (1a). Effect of herbicide or herbicide combination on spotted knapweed biomass at Rock Creek (1b). Herbicide treatments were: 1) none, 2) glyphosate at $0.5 \mathrm{~kg}$ a.i. $\left.\mathrm{ha}^{-1}, 3\right)$ picloram at $0.14 \mathrm{~kg}$ a.i. $\left.\mathrm{ha}^{-1}, 4\right)$ picloram at $0.28 \mathrm{~kg}$ a.i. ha ${ }^{-1}, 5$ ) clopyralid at $0.21 \mathrm{~kg}$ a.i. ha ${ }^{-1}$ plus $2,4-\mathrm{D}$ at $1.12 \mathrm{~kg}$ a.i. $\left.\mathrm{ha}^{-1}, 6\right)$ picloram at $0.14 \mathrm{~kg}^{-1 . i}$. ha ${ }^{-1}$ plus glyphosate $0.5 \mathrm{~kg}$ a.i. $\mathrm{ha}^{-1}, 7$ ) picloram at $0.28 \mathrm{~kg}_{\text {a.i. }} \mathrm{ha}^{-1}$ plus glyphosate at $0.5 \mathrm{~kg} \mathrm{a.i.}^{-1} \mathrm{ha}^{-1}$, and 8 ) clopyralid at 0.21 a.i. $\mathrm{ha}^{-1}$ plus $2,4-\mathrm{D}$ at $1.12 \mathrm{~kg}$ a.i. $\mathrm{ha}^{-1}$ plus glyphosate at $0.5 \mathrm{~kg}$ a.i. $\mathrm{ha}^{-1}$. 

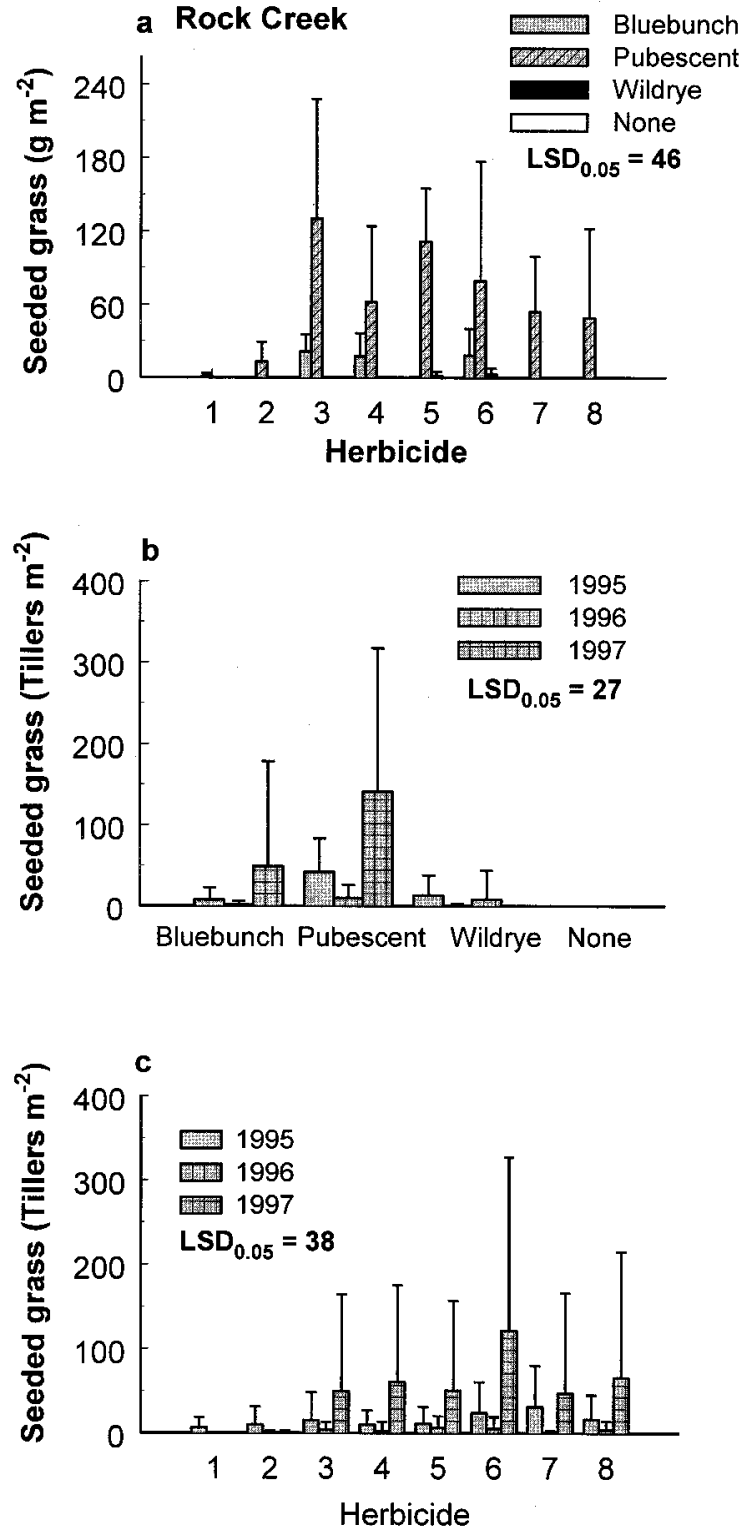

Fig. 2. Effect of herbicide or herbicide combination by year on seeded grass biomass Rock Creek (2a). Effect of species of seeded grass by year on seeded grass density at Rock Creek (2b). Effects of herbicide or herbicide combination by species of grass seeded on seeded grass biomass at Rock Creek (2c). Herbicide treatments were: 1) none, 2) glyphosate at $0.5 \mathrm{~kg}$ a.i. $\mathrm{ha}^{-1}, 3$ ) picloram at $0.14 \mathrm{~kg}$ a.i. $\left.\mathrm{ha}^{-1}, 4\right)$ picloram at $0.28 \mathrm{~kg}^{-1 . i}$. ha- $\left.{ }^{-1}, 5\right)$ clopyralid at $0.21 \mathrm{~kg}$ a.i. $\mathrm{ha}^{-1}$ plus 2,4-D at $1.12 \mathrm{~kg}$ a.i. $\left.\mathrm{ha}^{-1}, 6\right)$ picloram at $0.14 \mathrm{~kg}^{-1 . i}$. $\mathrm{ha}^{-1}$ plus glyphosate $0.5 \mathrm{~kg}$ a.i. ha ${ }^{1}$, 7) picloram at $0.28 \mathrm{~kg}_{\text {a.i. }} \mathrm{ha}^{-1}$ plus glyphosate at $0.5 \mathrm{~kg}^{-1 . i} \mathrm{ha}^{-1}$, and 8 ) clopyralid at 0.21 a.i. ha ${ }^{-1}$ plus $2,4-D$ at $1.12 \mathrm{~kg}$ a.i. $\mathrm{ha}^{-1}$ plus glyphosate at $0.5 \mathrm{~kg}^{\mathrm{a} . \mathrm{i} .} \mathrm{ha}^{-1}$.

Table 4. Mean squares generated from analysis of variance of biomass (1997) at Rock Creek, Mont.

Mean Squares

\begin{tabular}{lccccc} 
Source & df & Spotted knapweed & Seeded grass & Other grasses & Other forbs \\
\hline Block & 3 & 17826 & 1072 & $22151^{*}$ & 89 \\
Species & 3 & 6609 & $25084^{* 1}$ & 1210 & 42 \\
Block $*$ Species & 9 & 19320 & 859 & 10013 & 119 \\
Herbicide & 7 & $135534^{*}$ & $2288^{*}$ & $100533^{*}$ & $233^{*}$ \\
Species $*$ Herbicide & 21 & 10175 & $1644^{*}$ & 6424 & 32
\end{tabular}

Spotted knapweed biomass was dependent upon the herbicide or herbicide combination in 1997 (Table 2). Those treatments that included picloram yielded the lowest spotted knapweed biomass, ranging from 34 to $67 \mathrm{~g} \mathrm{~m}^{-2}$ (Fig. 1b). All other treatments yielded greater than $185 \mathrm{~g} \mathrm{~m}^{-2}$ of spotted knapweed.

\section{Seeded grasses}

The effect of herbicide or herbicide combination on seeded grass was dependent upon the year after treatment at Rock Creek (Table 1). In the first year (1995), those herbicide combinations including glyphosate had the highest seeded grass density (Fig. 2c). However, only picloram applied at $0.28 \mathrm{~kg}$ a.i. ha ${ }^{-1}$ plus glyphosate had higher seeded grass density than treatments excluding glyphosate or glyphosate applied alone. In 1996, all treatments produced similar seeded grass density, ranging from 0.6 to 6.3 plants $\mathrm{m}^{-2}$. By 1997 , treatments receiving $0.14 \mathrm{~kg}$ a.i. $\mathrm{ha}^{-1}$ of picloram plus glyphosate had over twice (121 plants $\mathrm{m}^{-2}$ ) the density of seeded grasses than any other treatments. Glyphosate applied alone produced the lowest seeded grass density ( 0.6 plants $\left.\mathrm{m}^{-2}\right)$ of all herbicide treatments.

Tiller density of seeded grass was also dependent upon species and year after seeding (Table 1). The first year after seeding (1995) pubescent wheatgrass had the highest grass density at Rock Creek (Fig. 2b). All other species had similar densities to the unseeded control that year. In 1996, all species had similar densities to the unseeded control. Pubescent wheatgrass density was 10 plants $\mathrm{m}^{-2}$ that year. By 1997, pubescent wheatgrass had the highest grass density (141 plants $\mathrm{m}^{-2}$ ). Bluebunch wheatgrass had the second highest density, which was about 49 plants $\mathrm{m}^{-2}$. The density of Russian wildrye was similar to unseeded control at Rock Creek that year.

Seeded grass biomass was dependent upon the species seeded and the herbicide or herbicide combination applied at Rock Creek in 1997 (Table 2). Plots receiving either picloram applied at $0.14 \mathrm{~kg}$ a.i. $\mathrm{ha}^{-1}$ or clopyralid plus 2,4-D and seeded with pubescent wheatgrass yielded greatest grass biomass (Fig. 2a). Other herbicide treatments including either picloram or clopyralid plus 2,4-D and seeded with pubescent wheatgrass yielded higher grass biomass than seeded with any other species. Biomass of bluebunch wheatgrass and Russian wildrye was similar to the unseeded control. Of the 2 species, bluebunch wheatgrass tended to produce more 
Table 3. Mean squares generated from analysis of variance of density at Hamilton, Mont.

\begin{tabular}{lccc}
\hline \hline & & \multicolumn{2}{c}{ Mean Squares } \\
\cline { 3 - 4 } Source & df & Spotted knapweed & Seeded grass \\
\hline Block & 3 & 1425 & $19202.8^{*}{ }^{1}$ \\
Species & 3 & $16178^{*}$ & $80193.2^{*}$ \\
Block* Species & 9 & 25152 & 7367.0 \\
Herbicide & 7 & $149220^{*}$ & $9200.2^{*}$ \\
Species *Herb & 21 & 7968 & 3741.9 \\
Block*Herb*Species & 84 & 7925 & 2812.3 \\
Year & 1 & $347282^{*}$ & $180613.5^{*}$ \\
Year*Species & 3 & $17468^{*}$ & $55883.3^{*}$ \\
Year*Herb & 7 & $29376^{*}$ & 2872.8 \\
Year*Species*Herb & 21 & 4308 & 2452.0 \\
Error & 92 & 6088 & 3895.9 \\
\hline
\end{tabular}

Table 4. Mean squares generated from analysis of variance of biomass (1997) at Hamilton, Mont.

\begin{tabular}{lccccc}
\hline \hline & & \multicolumn{4}{c}{ Mean Squares } \\
\cline { 3 - 5 } Source & df & Spotted knapweed & Seeded grass & Other grasses & Other forbs \\
\hline Block & 3 & 5875 & 30 & 51011 & 6.7 \\
Species & 3 & 2541 & $553^{* 1}$ & $27169^{*}$ & 2.0 \\
Block * Species & 9 & 2566 & 14 & 1845 & 1.8 \\
Herbicide & 7 & $20005^{*}$ & $211^{*}$ & $60915^{*}$ & 4.1 \\
Species * Herbicide & 21 & 1626 & $89^{*}$ & $6090^{*}$ & $3.8^{*}$ \\
Error & 93 & 2107 & 16 & 2929 & 2.0 \\
\hline
\end{tabular}

${ }^{1}$ Asterisk following mean square indicates significant F-test at $\mathrm{P} \leq 0.05$.

biomass than Russian wildrye. Other grass biomass, primarily smooth bromegrass and Kentucky bluegrass, increased over the unsprayed control and plots sprayed with glyphosate alone at Rock Creek (Fig. 3).

\section{Hamilton}

Spotted knapweed

The effect of herbicide or herbicide combination on spotted knapweed density was dependent upon the year after treatment at Hamilton (Table 1). At this site, all herbicide treatments that included picloram produced the lowest spotted knapweed density the first (1996) year after application, which ranged from about 15 to 23 plants $\mathrm{m}^{-2}$ (Fig. 4a). Treatments that included clopyralid plus 2,4-D had the highest spotted knapweed density that year. Glyphosate did not affect spotted knapweed density. In 1997, picloram applied at $0.14 \mathrm{~kg}$ a.i. ha ${ }^{-1}, 0.28 \mathrm{~kg}$ a.i. $\mathrm{ha}^{-1}$, and $0.28 \mathrm{~kg}$ a.i. ha ${ }^{-1}$ plus glyphosate had 44 , 28 , and 23 spotted knapweed plants $\mathrm{m}^{-2}$, respectively. Picloram applied at $0.14 \mathrm{~kg}$ a.i. ha ${ }^{-1}$ plus glyphosate had slightly higher spotted knapweed density than the other treatments including this herbicide. Treatments that included clopyralid plus 2,4-D or glyphosate alone increased spotted knapweed density over that of the untreated control.

The effect of species on spotted knapweed density depended upon year (Table spotted knapweed plants than plots seeded with either pubescent wheatgrass or bluebunch wheatgrass. In 1997, all seeded species reduced spotted knapweed density below that of the unseeded control by more than 45 plants $\mathrm{m}^{-2}$.

At Hamilton, spotted knapweed biomass was lowest in those treatments that included picloram in 1997 (Table 4; Fig. 4c). Spotted knapweed biomass ranged from 9 to $15 \mathrm{~g} \mathrm{~m}^{-2}$ in plots treated with picloram. All other treatments yielded spotted knapweed biomass similar to that of the untreated control.

\section{Seeded grasses}

Grass density was dependent upon the species and year after seeding (Table 3). In 1996, pubescent wheatgrass and bluebunch wheatgrass had the highest seedling density (about 120 plants $\mathrm{m}^{-2}$ ) (Fig. 5b). Russian wildrye had 18 plants $\mathrm{m}^{-2}$ that year, which was similar to that of the unseeded control. In the second year (1997), all grass species had similar density as that of the unseeded control. However, analysis of variance of the 1997 data alone indicated pubescent wheatgrass and bluebunch wheatgrass had densities higher than that of the unseeded control (Table 3; Fig. 5c).

Seeded grass biomass was dependent upon herbicide or herbicide combination and species of grass seeded (Table 4).
3). The first year after seeding (1996) spotted knapweed density was similar to the unseeded control regardless of grass species seeded (Fig. 4b). However, plots seeded with Russian wildrye had fewer

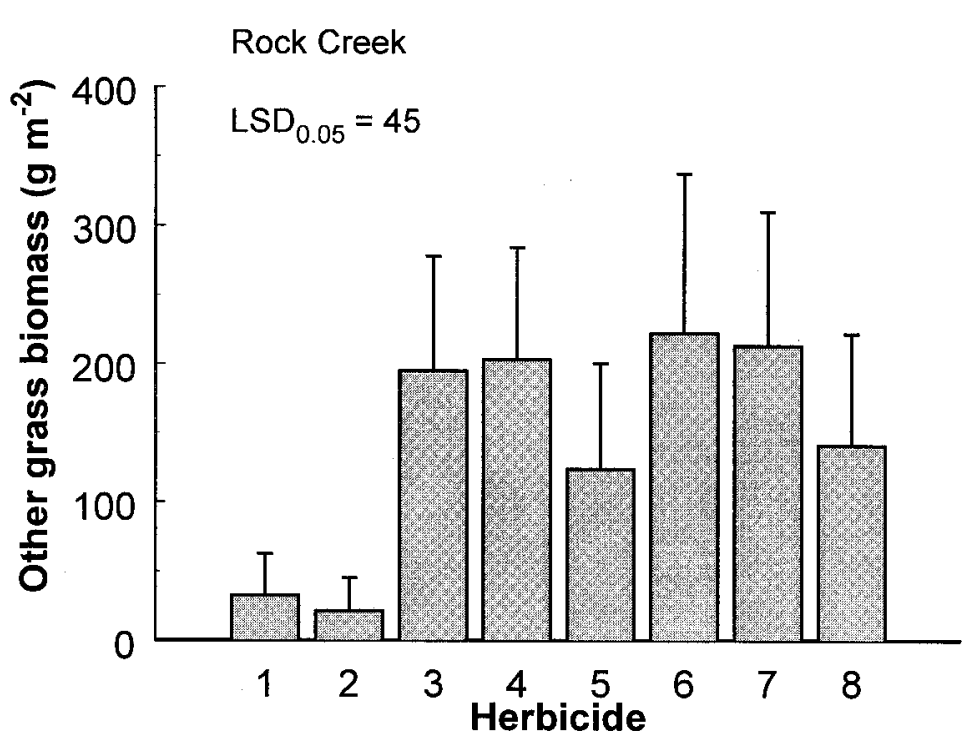

Fig. 3. Effect of herbicide and herbicide combinations on biomass of grasses other than those seeded at Rock Creek. Herbicide treatments were: 1) none, 2) glyphosate at $0.5 \mathrm{~kg} \mathrm{a.i.}^{-1}$, 3) picloram at $0.14 \mathrm{~kg}$ a.i. $\mathrm{ha}^{-1}$, 4) picloram at $0.28 \mathrm{~kg}^{\text {a.i. }}$ ha $^{-1}$, 5) clopyralid at $0.21 \mathrm{~kg}$ a.i. $\mathrm{ha}^{-1}$ plus 2,4-D at $1.12 \mathrm{~kg}$ a.i. $\mathrm{ha}^{-1}, 6$ ) picloram at $0.14 \mathrm{~kg}^{\mathrm{a} . i .} \mathrm{ha}^{-1}$ plus glyphosate $0.5 \mathrm{~kg}$ a.i. $\left.\mathrm{ha}^{-1}, 7\right)$ picloram at $0.28 \mathrm{~kg}$ a.i. ha ${ }^{-1}$ plus glyphosate at $0.5 \mathrm{~kg}^{-1 . i} \mathrm{ha}^{-1}$, and 8) clopyralid at 0.21 a.i. ha ${ }^{-1}$ plus $2,4-D$ at $1.12 \mathrm{~kg}$ a.i. ha ${ }^{-1}$ plus glyphosate at $0.5 \mathrm{~kg}^{\mathrm{a} . \mathrm{i} .} \mathrm{ha}^{-1}$. 

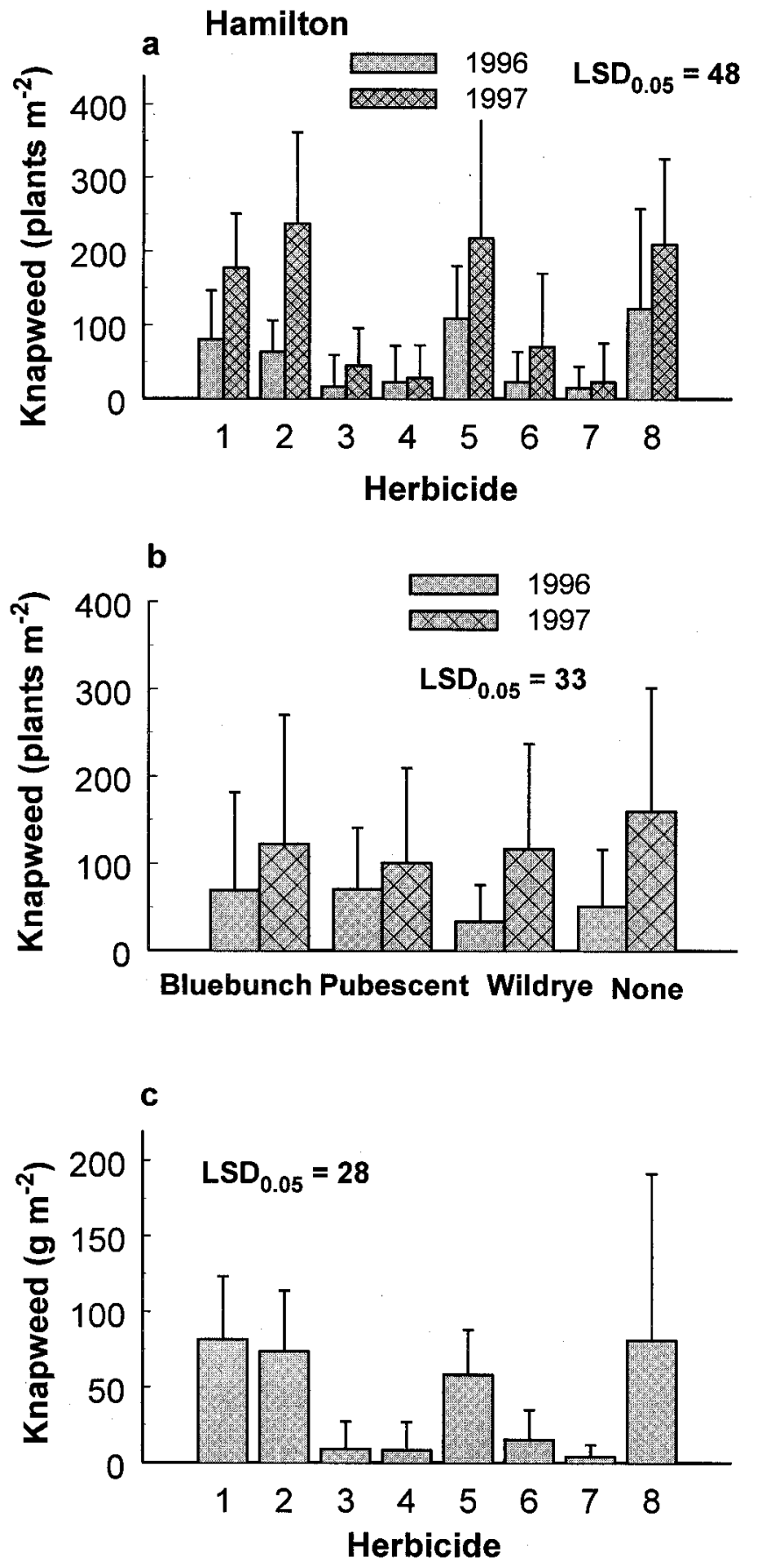

Fig. 4. Effect of herbicide or herbicide combination by year on spotted knapweed density at Hamilton (4a). Effect of species seeded on spotted knapweed density at Hamilton (4b). Effect of herbicide or herbicide combination on spotted knapweed biomass at Hamilton

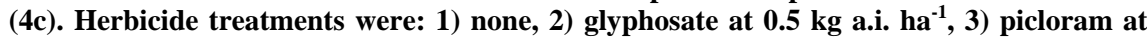
$0.14 \mathrm{~kg}$ a.i. $\left.\mathrm{ha}^{-1}, 4\right)$ picloram at $0.28 \mathrm{~kg}$ a.i. $\mathrm{ha}^{-1}, 5$ ) clopyralid at $0.21 \mathrm{~kg}$ a.i. ha ${ }^{-1}$ plus 2,4-D at $1.12 \mathrm{~kg}$ a.i. $\mathrm{ha}^{-1}, 6$ ) picloram at $0.14 \mathrm{~kg}^{2}$ a.i. $\mathrm{ha}^{-1}$ plus glyphosate $0.5 \mathrm{~kg}$ a.i. ha- $\left.{ }^{-1}, 7\right)$ picloram at $0.28 \mathrm{~kg}$ a.i. ha ${ }^{-1}$ plus glyphosate at $0.5 \mathrm{~kg}$ a.i. ha ${ }^{-1}$, and 8) clopyralid at 0.21 a.i. ha ${ }^{-1}$ plus 2,4-D at $1.12 \mathrm{~kg}$ a.i. ha ${ }^{-1}$ plus glyphosate at $0.5 \mathrm{~kg}$ a.i. $\mathrm{ha}^{-1}$.
Pubescent wheatgrass had the greatest biomass in plots where significant establishment occurred (Fig. 5a). Picloram applied at $0.14 \mathrm{~kg}$ a.i. $\mathrm{ha}^{-1}$ plus glyphosate yielded greatest pubescent wheatgrass biomass, which was $24 \mathrm{~g} \mathrm{~m}^{-2}$. Picloram applied at $0.28 \mathrm{~kg}$ a.i. ha ${ }^{-1}$ yielded $19 \mathrm{~g} \mathrm{~m}^{-2}$ of pubescent wheatgrass biomass. Picloram applied at $0.14 \mathrm{~kg}$ a.i. $\mathrm{ha}^{-1}$ and picloram applied at $0.28 \mathrm{~kg}$ a.i. ha ${ }^{-1}$ plus glyphosate yielded 16 and $15 \mathrm{~g} \mathrm{~m}^{-2}$, respectively. Plots treated with picloram at $0.28 \mathrm{~kg}$ a.i. $\mathrm{ha}^{-1}, 0.14 \mathrm{~kg}$ a.i. ha ${ }^{-1}$ plus glyphosate, or $0.28 \mathrm{~kg}$ a.i. $\mathrm{ha}^{-1}$ plus glyphosate and seeded with bluebunch wheatgrass had greater grass biomass than the unseeded control. Plots treated with picloram at $0.14 \mathrm{~kg}$ a.i. ha ${ }^{-1}$, $0.14 \mathrm{~kg}$ a.i. $\mathrm{ha}^{-1}$ plus glyphosate, or 0.28 $\mathrm{kg}$ a.i. ha ${ }^{-1}$ plus glyphosate and seeded with Russian wildrye had greater grass biomass than the unseeded control. Clopyralid plus 2,4-D and/or glyphosate did not affect grass biomass.

Cheatgrass biomass was dependent upon herbicide or herbicide combination and species of grass seeded at Hamilton (Table 4). Clopyralid plus 2,4-D and/or glyphosate did not affect cheatgrass biomass (Fig. 6). In all herbicide treatments that included picloram, pubescent wheatgrass yielded the lowest cheatgrass biomass.

\section{Discussion}

In many cases, revegetating spotted knapweed infested rangeland fails because of insufficient soil moisture and/or intense weed competition (Velagala et al. 1997). Our study indicates that picloram at either 0.14 or $0.28 \mathrm{~kg}$ a.i. $\mathrm{ha}^{-1}$ applied in the latefall provided consistent control of spotted knapweed for up to 3 years. Including glyphosate with picloram did not affect spotted knapweed biomass or the biomass of grasses other than those seeded. In addition, those treatments that included picloram yielded the greatest seeded grass biomass, apparently as a response to effective weed control.

Glyphosate applied alone is often recommended for weed control prior to fall-dormant seeding of many grasses with the objective of controlling all undesirable vegetation for a brief period (Dewey et al. 1997, Jacobs et al. 1998). Glyphosate reduced spotted knapweed and increased grass establishment the first year after application. However, spotted knapweed density increased over the control in subsequent years. Correspondingly, grass establishment was lowest in plots when glyphosate was applied alone. We specu- 

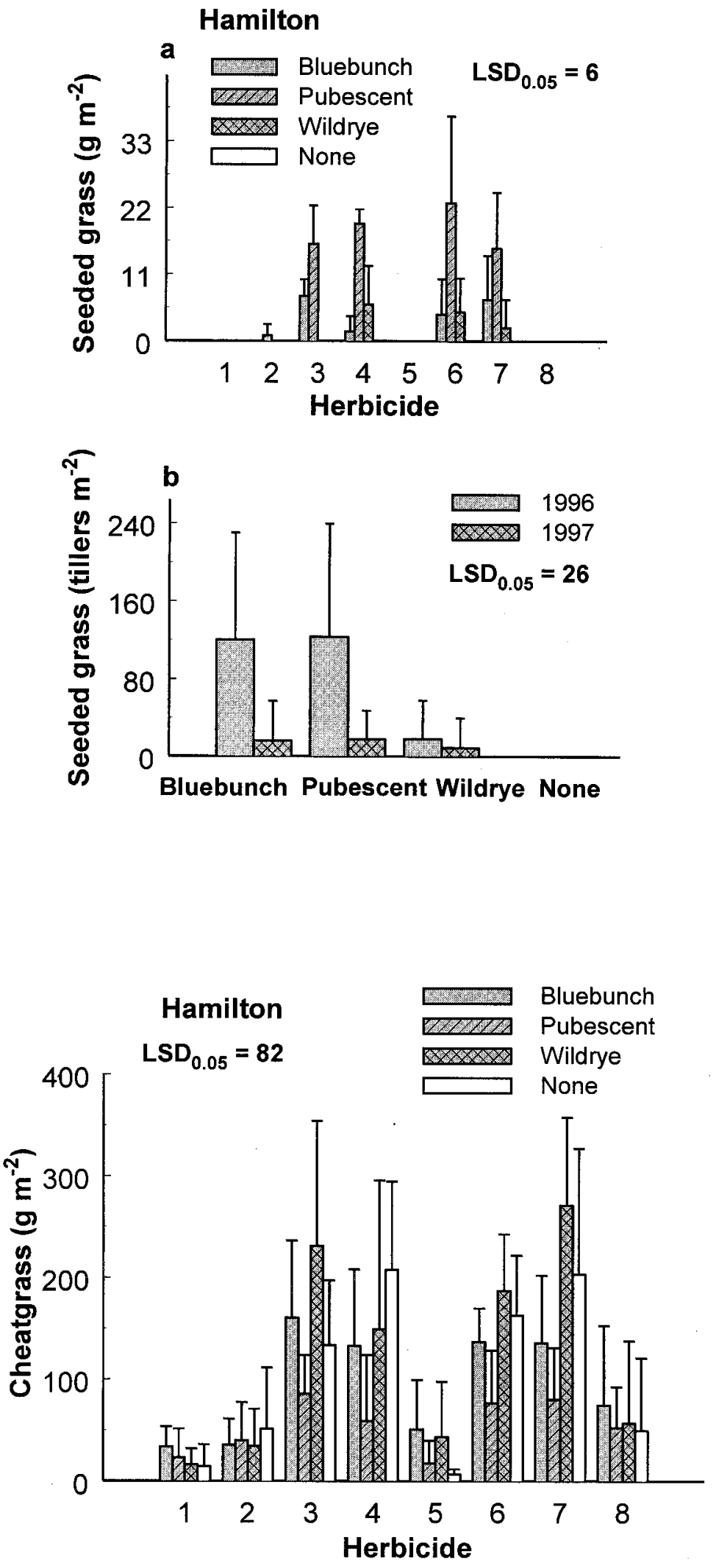

Fig. 5. Effect of species seeded by year after seeding on seeded grass biomass at Hamilton (5a). Effect of herbicide or herbicide combination by species of grass seeded on seeded grass density at Hamilton (5b). Herbicide treatments were: 1) none, 2) glyphosate at $0.5 \mathrm{~kg}$ a.i. $\left.\mathrm{ha}^{-1}, 3\right)$ picloram at $0.14 \mathrm{~kg}$ a.i. $\mathrm{ha}^{-1}, 4$ ) picloram at $\left.0.28 \mathrm{~kg}^{\text {a.i. }} \mathrm{ha}^{-1}, 5\right)$ clopyralid at $0.21 \mathrm{~kg}$ a.i. ha $^{-1}$ plus $2,4-\mathrm{D}$ at $1.12 \mathrm{~kg}$ a.i. $\left.\mathrm{ha}^{-1}, 6\right)$ picloram at $0.14 \mathrm{~kg}$ a.i. $\mathrm{ha}^{-1}$ plus glyphosate $0.5 \mathrm{~kg}$ a.i. $\mathrm{ha}^{-1}, 7$ ) picloram at $0.28 \mathrm{~kg}$ a.i. ha $^{-1}$ plus glyphosate at $0.5 \mathrm{~kg}$ a.i. ha ${ }^{-1}$, and 8) clopyralid at 0.21 a.i. ha ${ }^{-1}$ plus 2,4-D at $1.12 \mathrm{~kg}$ a.i. $\mathrm{ha}^{-1}$ plus glyphosate at $0.5 \mathrm{~kg}$ a.i. $\mathrm{ha}^{-1}$.
Fig. 6. Effect of herbicide or herbicide combination by species of grass seeded on cheatgrass biomass at Hamilton. Herbicide treatments were: 1) none, 2) glyphosate at $0.5 \mathrm{~kg}$ a.i. $\left.\mathrm{ha}^{-1}, 3\right)$ picloram at $0.14 \mathrm{~kg}$ a.i. $\left.\mathrm{ha}^{-1}, 4\right)$ picloram at $0.28 \mathrm{~kg}$ a.i. ha ${ }^{-1}, 5$ ) clopyralid at $0.21 \mathrm{~kg}$ a.i. ha ${ }^{-1}$ plus 2,4-D at $1.12 \mathrm{~kg}$ a.i. $\mathrm{ha}^{-1}$, 6) picloram at $0.14 \mathrm{~kg}$ a.i. ha ${ }^{-1}$ plus glyphosate $0.5 \mathrm{~kg}$ a.i. ha-1, 7) picloram at $0.28 \mathrm{~kg}^{-1 . i} \mathrm{ha}^{-1}$ plus glyphosate at $0.5 \mathrm{~kg}^{\text {a.i. }} \mathrm{ha}^{-1}$, and 8 ) clopyralid at 0.21 a.i. ha $^{-1}$ plus $2,4-\mathrm{D}$ at $1.12 \mathrm{~kg}$ a.i. ha ${ }^{-1}$ plus glyphosate at $0.5 \mathrm{~kg}$ a.i. ha ${ }^{-1}$. 
late that glyphosate temporarily opened niches for both spotted knapweed and seeded grasses the first year. However, by the third season, spotted knapweed out-competed the seeded grasses, and consequently, glyphosate ultimately increased spotted knapweed and resulted in seeding failure.

In treatments where grasses successfully established, 'Luna' pubescent wheatgrass consistently yielded the highest density and biomass. Of 11 grasses studied by Ferrell et al. (1998), 'Luna' pubescent wheatgrass maintained the best stand in no-till drilled plots. In that study, ' Bezoisky' Russian wildrye and 'Luna' pubescent wheatgrass showed the most promise for successful competition with leafy spurge (Euphorbia esula L.). However, in this study, 'Bozoisky' Russian wildrye was the poorest establishing grass. 'Goldar' bluebunch wheatgrass, a native species, did not establish as well as 'Luna' pubescent wheatgrass, but based on density and biomass developed a successful stand in plots where picloram was applied.

Although revegetation with aggressive species has been shown to limit weed reinvasion (Lym et al. 1997), managers are reluctant to attempt it because of the number of attempts required for success and the number of entries onto a site needed to maximize the potential for seedling establishment. We believe that a single-entry revegetation program applying picloram in late-fall during a fall-dormant seeding will maximize seedling establishment in spotted knapweed infested rangeland. Our single entry revegetation strategy may provide managers with a cost effective and reliable revegetation strategy and ultimately a sustainable weed management program.

\section{Literature Cited}

Dewey, S.A., R.L. Sheley, and T.D. Whitson. 1997. 1997-1998 Montana-Utah-Wyoming Weed Management Handbook. Montana State Univ. Exten. Serv. 283 p.

Ferrell, M.A., T.D. Whitson, D.W. Koch, and A.E. Gade. 1998. Leafy spurge (Euphorbia esula) control with several grass species. Weed Technol. 12:374-380.

Forcella, F. and S. J. Harvey. 1980. New and Exotic weeds of Montana. II: migration and distribution of 100 alien weeds in northwestern USA, 1881-1980. Montana State Univ. Herbarium, Bozeman, Mont. 117p.

Jacobs, J.S., R.L. Sheley, and M.L. Carpinelli. 1998. Revegetation of weed infested rangeland: what we've learned. Rangelands. 20:10-15.

James, D. 1992. Some principles and practices of desert revegetation seeding. Arid Lands Newsletter. 32:22-27.

Lacey, J. R., C. B. Marlow, and J. R. Lane. 1989. Influence of spotted knapweed (Centaurea maculosa) on surface water runoff and sediment yield. Weed Technol. 3:627-631.

Lym, R.G. and D.A. Tober. 1997. Competitive grasses for leafy spurge (Euphorbia esula) reduction. Weed Technol. 11:787-792

Mueggler, W.F. and W.L. Stewart 1980. Grassland and shrubland habitat types of western Montana. USDA Forest Service general technical report Int-66 $154 \mathrm{p}$.

Peterson, R.G. 1985. Design and analysis of experiments. Marecel Dekker, Inc. New York.

Rees, N. E., P. C. Quimby, Jr., G. L. Piper, E. M. Coombs, C. E. Turner, N. R. Spencer, and L. V. Knutson. 1996. Biological control of weeds in the west. Western Soc. of Weed Sci., USDA Agr. Res. Serv., Montana Dept. Agr., Montana State Univ.
Sheley, R. L. and J. S. Jacobs, 1997. Response of spotted knapweed and grass to picloram and fertilizer combinations. J. Range Manage. 50:263-267.

Sheley, R.L., J.S. Jacobs, and M.L. Carpinelli. 1998. Distribution, biology, and management of diffuse (Centaurea diffusa) and spotted knapweed (Centaurea maculosa). Weed Technol. 12:353-362.

Sheley, R. L., T. J. Svejcar, and B. D. Maxwell. 1996. A theoretical framework for developing successional weed management strategies on rangeland. Weed Technol. 10:712-720.

Spoon, C. W., H. R. Boweles, and A. Kulla 1983. Noxious weeds on The Lolo National Forest. A situation analysis staff paper. USDA Forest Ser. North. Reg. 33p.

Tyser, R. W. and C. H. Key. 1988. Spotted knapweed in natural area fescue grasslands: An ecological assessment. Northwest Sci. 62:981-987.

Velagala, R. P., R. L. Sheley, and J. S. Jacobs. 1997. Influence of density on intermediate wheatgrass and spotted knapweed interference. J. Range Manage. 50:523-529.

Watson, A. K., and A. J. Renny. 1974. The biology of Canadian weeds. 6. Centaurea diffusa and C. Maculosa. Can. J. Plant Sci. 54:687-701. 